\title{
3D pharmacophore alignments: does improved geometric accuracy affect virtual screening performance?
}

\author{
Gerhard Wolber $^{1 *}$, T Seidel $^{2}$, F Bendix $^{2}$ \\ From 5th German Conference on Cheminformatics: 23. ClC-Workshop \\ Goslar, Germany. 8-10 November 2009
}

Virtual screening using three-dimensional arrangements of chemical features (3D pharmacophores) has become an important method in computer-aided drug design. Although frequently used, considerable differences exist in the interpretation of these chemical features and their corresponding 3D overlay algorithms. We have recently developed an efficient and accurate 3D alignment algorithm based on a pattern recognition technique [1]. In the presented work, we extend this algorithm to be used for high-performance virtual database screening and investigate, whether applying this geometrically more accurate 3D alignment algorithm improves virtual screening results over conventional incremental n-point distance matching approaches.

\footnotetext{
Author details

${ }^{1}$ University of Innsbruck, Institute of Pharmacy, Dept. Pharmaceutical Chemistry, Innrain 52, 6020 Innsbruck, Austria. ${ }^{2}$ Inte:Ligand GmbH,

Mariahilferstrasse 74B/11, A-1070 Vienna, Austria.
}

Published: 4 May 2010

\section{Reference}

1. Wolber G, Dornhofer A, Langer T: Efficient overlay of small molecules using 3-D pharmacophores. J Comput-Aided Mol Design 2006, 20(12):773-788.

doi:10.1186/1758-2946-2-S1-010

Cite this article as: Wolber et al:: 3D pharmacophore alignments: does improved geometric accuracy affect virtual screening performance? Journal of Cheminformatics 2010 2(Suppl 1):010.

* Correspondence: gerhard.wolber@uibk.ac.at

'University of Innsbruck, Institute of Pharmacy, Dept. Pharmaceutical

Chemistry, Innrain 52, 6020 Innsbruck, Austria

Publish with ChemistryCentral and every scientist can read your work free of charge

"Open access provides opportunities to our colleagues in other parts of the globe, by allowing anyone to view the content free of charge."

W. Jeffery Hurst, The Hershey Company.

- available free of charge to the entire scientific community

- peer reviewed and published immediately upon acceptance

- cited in PubMed and archived on PubMed Central

- yours - you keep the copyright

Submit your manuscript here

http://www.chemistrycentral.com/manuscript/

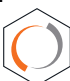
Chemistry Central 